\title{
Islamic Legal Education in the 4.0 Era: Does It Need to Consider Technology?
}

\author{
Windy Triana \\ State Islamic University Syarif Hidayatullah \\ Jakarta, Indonesia \\ windytriana@uinjkt.ac.id
}

\begin{abstract}
This paper discusses the encountering of Islamic legal education with the advancement of technology. Islamic legal education that is identical with a more traditional type of legal education, in fact, cannot avoid considering the need for technology in this 4.0 era. This study is built upon the reflection of the practice of Islamic legal education in the Faculty of Sharia and Law of State Islamic University SyarifHidayatullah Jakarta and a survey on various literature on the relationship between legal education and technology. It is found that the respond of Islamic legal education to the advancement of technology is exceptionally slow. In fact, the adoption of technology is needed not only to respond to the use of technology by the Islamic judiciary but also to make the Islamic legal education more effective with the evolvement of technology-based teaching aids.
\end{abstract}

Keywords: Islamic legal education, technology, legal education

\section{INTRODUCTION}

Legal education, in general, is known to be slow in responding to the development of technology. This is even more with Islamic legal education that is presumed to be closely related to a more traditional legal education, with most of its resources come from the Islamic scholars from many centuries ago. However, current development demands Islamic legal education also to follow 21 st century trends.

Indonesian Islamic judiciary, for example, has upgraded its system with the adoption of technology in its systems. These include the online court decisions, an e-learning program for judges, and the newly developed E-Court system[1], [2]. Nevertheless, this development has not been promptly responded by Islamic legal education in Sharia and Law faculties. Either legal technology skills or technological-based legal learning has not yet been seriously considered.

Apart from the use of technology in Islamic judiciary, the question remains "why does Islamic legal education need to consider the technology?". More questions to follow are "what kind of technology to be taught to the Islamic law students?" and "how to teach the technology to the students?"

This paper aims at answering these questions by looking at the practice of Islamic legal education in the Faculty of Sharia and Law of State Islamic University SyarifHidayatullah Jakarta and surveying various kinds of literature on legal education and technology. The latest is to see the best practices from various law

\author{
Khamami Zada \\ State Islamic University Syarif Hidayatullah \\ Jakarta, Indonesia \\ khamami@uinjkt.ac.id
}

schools around the world that adopt technology in their educational system.

State Islamic University SyarifHidayatullah Jakarta is one of the oldest and most prominent Islamic higher education in Jakarta. The faster progress of the institutions compared to other Islamic campuses in many ways is benefited by its location in the capital city of Indonesia. This institution often becomes a benchmark for others.

Islamic legal education in University is conducted by the Faculty of Sharia and Law. The Faculty offers not only the study of Islamic law but also the national law. Students with specific major in Islamic law, such as Islamic Criminal Law, are also taught national law. In its development, the Islamic legal education in the Faculty has moved from the traditional approach to a more unconventional one by ensuring the practicality and applicability of the courses taught.

\section{A. Why does Islamic legal education need to consider technology?}

In general, Kennedy M. Maranga points out that there are at least two reasons why legal education needs to evolve the technology. First, the advancement of technology has led to the adoption of technology in the judiciary. Second, legal education can be more effective with the use of technological teaching aids. This means that the development of technology has influenced both legal practices and legal education.[3]

Moreover, current legal professors face the challenge to teach students that are heavily exposed to technology. Taking technology into classrooms becomes inevitable in dealing with the so-called millennial students. As they are exposed to various advanced technological devices (computers and smartphones) and social media (Facebook, Instagram and Twitter). Since technology has also been incorporated in lower education, it is expected that legal education also starts to adopt it.[4]

Several law schools around the world have already used technology in their systems. In this case, they believe that the law schools need to adapt current situation considering that students' exposure to technology can help them keep up with the new development in the judiciary, and the enhance the marketability of their graduates.[5] 
In Australia, for example, in 2016, there were 36 law schools that included technology in the educational system to expose their students with technical literacy.[5] Even some law schools have developed digital application to help their students learning legal technology. Another step is to develop courses on law and technology. Such courses become importance considering that current legal professionals need to deal with the use of technology in courts and legal cases related to technology.[5]

In Indonesia, the Islamic judiciary has experienced digital transformation. The online court decisions platform has been developed to a more advanced 'E-Court' system. The E-Court system was launched in 2018 based on the Supreme Court Regulation No. 3 of 2018. This system is developed to create a more simple, faster and lower cost court services. Also, the system is expected to provide better access to justice,[2], [6] as is in many other jurisdictions.[7], [8] E-Court, which was developed by the Supreme Court of Indonesia, consists of efiling, e-payment, and e-summons. The system is accessible via https://ecourt.mahkamahagung.go.id/. This has been considered the "massive jump" of the Indonesian judicial system,[2] and is expected to be used by the judicial personnel and justice seekers, including lawyers.[2]

Even before the development of E-Court, the Islamic judiciary in Indonesia had been more advanced in the technological innovation compared to other courts. This was begun with the development of the prototype of SIADPA (Sistem Administrasi Perkara Pengadilan Agama/ Religious Courts Case Administration System) in 1998. In 1999, there were four Religious Courts in Surabaya applying the system. This innovation then is developed to enhance the performance of the judiciary in general. In 2010, SIADPA system was transformed into SIADPA Plus; and in 2015, the program was integrated into a new system called SIPP (Case Tracking Information System). Finally, in 2018, the Supreme Court unified all-digital system into E-Court.[1]

To support the use of this system, the Supreme Court provides a special training website, https://training-ecourt.mahkamahagung.go.id/. Thus, the users can train themselves how to use it. However, instant training itself is not sufficient. To enable the court personnel and lawyers to use the system more effectively, there is a need to accustom them with technology earlier.[3], [9], [10] This can be done during their tertiary education in the faculty of Sharia and Law.

With the progress in the Indonesian judiciary, Islamic legal education needs to be more responsive in preparing the graduates who are expected to be professionals in the field. With the exposure to technological literacy, the students will be more prepared to face the challenge of a more futuristic court system. Furthermore, Maranga argues that technology can make legal education more effective with the help of technology in analysing legal matters, conducting legal research, collecting and sorting facts, and writing.[3] Maranga also quotes Hilyard, who argues that electronic legal research has led to the more diverse legal theory framing.[3]

\section{B. "What Kind of Technology to be Taught to the Islamic Law Students?"}

To discuss the types of technology to be taught to Islamic law students, it can be started by referring to the reasons why the technology is needed in Islamic legal education. Which are to expose students with technical literacy, and keep up with the legal technology applied by the judiciary,[11] and legal research and writing. This means that the students are taught the existing technological-based legal application, the use of e-resources, digital referencing systems, and other technological-based teaching aids.

Paliwal divides three kinds of technology in legal education such as Computer Assisted Learning (CAL), the application of technology in law, and the technology-related substantive law. With regards to the CAL in legal education, Paliwala notes that the most significant innovation in the area is the development of Lexis in the United States and Eurolex in Europe. Both systems have changed the traditional approach to legal education into more technological-based approach with wider variety of legal cases.[12]

In the context of Islamic Legal Education, the need for the adoption of technology is also based on the above reasons. First, there is a need for Islamic legal education to adjust to the advancement of technology in the judiciary. The progress in adapting technology is rather faster in the Indonesian judiciary compared to the Islamic legal education operated by the Faculty of Sharia and Law of Islamic Higher Education Institutions in Indonesia.[1]Second, The need to accustom students and expose them to technology in general and in law-related technology. The last is the need for the development of technology-related substantive law, such as Law No. 11 of 2008 on Electronic Information and Transaction.

With the students' exposure to technology, it is expected that the students will be able to adapt with new technology used in their future professional fields. This is considering the wider agenda of providing better access to justice with the use of technology in various aspects of law in Indonesia.

However, looking at the practice of Islamic legal education in the Faculty of Sharia and Law, the response to the advancement of legal technology is relatively slow. Not only the faculty has not introduced the use of technology in the judiciary to the students but also has not yet encouraged the use of technology in teaching and learning activities.There are various ways can be taken to introduce students to technology in the learning of law, legal research, and law in judiciary. 


\section{C. "How to Teach Technology to the Students?"}

To address those needs, teaching technology to the students can be in two ways. The first is by developing special subjects that are directly connected to the use of legal technology. The second is by integrating the use of technology in various legal subjects.[13]

Looking at the curriculum of the Faculty of Sharia and Law of State Islamic University SyarifHidayatullah Jakarta, courses related to the use of technology in the judiciary is still absent. There is still no special subject on the use of technology for legal purposes. Furthermore, a closer look at the courses related to the procedural law in Indonesia comes up with a similar finding. The advancement of technology in Islamic judiciary in Indonesia has not been touched by the legal education curriculum at the Faculty.

With the lack of attention for a special subject on law and technology, therefore, the integration of technology in various subject becomes crucial. Some teachers have already used technology to communicate learning materials and other learningrelated matters using Google Classroom. However, there have been very limited teachers make use of the technological means in teaching and learning. Moreover, the program used is limited to Google Classroom or Zoom Cloud.

With regards to support students' writing and research skills, some teachers have already introduced students with the use of digital resources databases. The use of the databases enables students to expand their research and enhance their research skills. For the study of Islamic law in Indonesia and general contexts, some digital resource databases introduced to the students include SHARIAsource,[14] hukumonline.com, Lexadin, and JDIH MahkamahAgung. SHARIAsource is web-based Islamic legal resources developed by Harvard Law School that provide various primary sources of Islamic law from many countries, and various works on Islamic law, from the historical to contemporary issues.[14] Hukumonline.com, on the other hand, a website that provides various information on Indonesian legal issues. This website is useful for students to start their research and search for background information for their research. To do a comparative legal study, students can use lexadin.nl to enable them search various legal documents from all countries around the world. The next is JDIH MahkamahAgung that provides Indonesian legal documents, court decisions, including those issued by the Islamic courts in Indonesia or known as Religious Courts.

For legal journals, Islamic legal students can access them via Garuda, a web-managed by the Ministry of Research, Technology and Higher Education. This portal provides access to all journals published in Indonesia. Students can also access international journal databases as the Jakarta UIN subscribes to several journal databases such as Sage Publishing, JSTOR, Oxford Islamic Studies Online,
Cambridge University Press, etc. However, there is still a challenge in accessing these international databases, which is the availability of the internet access provided by the University.

Other potential programs to be introduced to students also include the use of referencing system, which some of them are available for free (Zotero, Mendeley, etc.) With this automatic referencing system, students will be exposed to the use of an automatic system and become more equipped with digital and technical literacy.There are more programs that can be used in legal education. These include online legal instructions, legal apps, adaptive learning materials, and games-based learning.[9] These are mainly developed for "Western" law schools. The advancement of technology can be useful for the 4.0 generation legal students to create innovations in legal apps.[15]

\section{Challenges in the Use of Technology in Islamic Legal Education}

The introduction and use of those technological means in Islamic legal education in the Faculty is not easy. Some existing issues relate the availability of supporting infrastructures, the teachers' skills and willingness, and the systematic approach by the Faculty to enforce the use of technology in teaching and learning system.

In terms of infrastructures, the issue is related to the availability of free internet access with the campus. To access international journal databases, students need to use the University's IP address. However, students often find it hard to access the University's WIFI. Second, teachers lack skills and willingness to use and introduce students with technology in learning. Their lack of skills is related to the absence of systematic approach by the Faculty in enhancing teachers' skills and knowledge on technology for legal teaching. Because of this, the use of technology is merely implemented by individual teachers sporadically. This means that not all students will have similar learning experience.

The latest issue is pertaining to students' English skills. The available access to various resources is hampered by the lack of skills in reading English materials. In this case, students prefer to use materials in the Indonesian language. This also happens among the teachers. Not all of the teachers have skills in reading and understanding English materials. Therefore, their skill in accessing those resources may not become optimal without their ability to understand resources written in English.

Looking at those issues, Islamic legal education seems to be left behind in the use of technology in teaching and learning process. Facing those problems, the Faculty and the University need to implement a more systematic approach to enhance teachers' skills in the use of technology in teaching and reading various resources in English. In this case, the Faculty and University should provide sufficient training for the teachers. The training needs to be done 
continuously in considering that not all teachers are able to absorb the idea in one or two series of training as some of them may have a lack exposure to the use of technological devices.

Without the awareness and eagerness of the Faculty to develop teachers' skill and introduce students to the use of technology in legal discipline, the Islamic legal education will not be able to catch up with the progress in the Islamic judiciary. As a consequence, the Faculty fails in preparing students to enter legal professional fields where technology has been in use. Moreover, the introduction of technology to Islamic law students will encourage them to make technological innovation in law or Islamic law, in particular.

\section{CONCLUSION}

In sort, with the on-going application and continuous innovation of technology in general judiciary and Islamic judiciary, there is a need for Islamic legal education to move beyond the traditional approach in teaching and learning. Legal education, in general, has moved into more technological-based education. However, this is not the case with Islamic legal education. It seems that Islamic legal education has been left behind in implementing technology in the teaching and learning process. The Sharia and Law Faculty has been very slow in responding to the advancement of technology. This also means that Islamic judiciary in Indonesia has even moved faster to the digital platform, compared to the Islamic legal institution. Even though there are some aspects of technology that are already implemented, but they are not systematically encouraged by the faculty and applied sporadically by only a few lecturers.

\section{ACKNOWLEDGMENT}

This work is presented in the International Conference on Islam, Science and Technology, held in Lombok, Indonesia from 8-10 October 2019.

\section{REFERENCES}

[1] W. Triana, "Internet, Islamic Judiciary and Production of Legal Knowledge," presented at the 19th Annual International Conference on Islamic Studies, Jakarta, 2019.

[2] JRTO, "Mahkamah Agung RI Meresmikan Aplikasi ECourt," 13-Jul-2018.

[3] K. M. Maranga, "The Role and Impact of Technology in Legal Education," Leg. Educ. Technol.

[4] M. Pistone, "Law Schools and Technology: Where We Are and Where We Are Heading," J. Leg. Educ., p. 19.

[5] "Technology in legal education." [Online]. Available: https://www.lawinorder.com.au/blog/august-

2016/technology-in-legal-education. [Accessed: 25-Oct2019].

[6] "Aplikasi E-Court Demi Peradilan Cepat dan Biaya Ringan," hukumonline.com, 17-Jul-2018. [Online]. Available:

https://www.hukumonline.com/berita/baca/lt5b4da2b0a085 3/aplikasi-e-court-demi-peradilan-cepat-dan-biaya-ringan/. [Accessed: 12-Sep-2019].

[7] N. Rishwain, "How Courts Can Increase Access to Justice by Adopting Better Technology," GPSolo, vol. 36, no. 1, pp. 40-43, Feb. 2019.

[8] J. J. Prescott, "Improving Access to Justice in State Courts with Platform Technology," Vanderbilt Law Rev., vol. 70, no. 6, pp. 1993-2050, Nov. 2017.

[9] M. Blissenden, "Teaching Undergraduate Law Students in the 21 st Century - Pedagogy in a Technological Era," ATHENS J. LAW, vol. 1, no. 4, pp. 213-220, Sep. 2015.

[10] C. Broussard, K. Brown, D. Cordova, and S. K. C. Mauldin, "Teaching Legal Technology," AALL Spectr., no. 4, pp. 22-25, 20172016.

[11] M. Smith, "Integrating technology in contemporary legal education," Law Teach., Aug. 2019.

[12] A. Paliwala, "Creating an academic environment: The development of technology in legal education in the United Kingdom," Int. Rev. Law Comput. Technol., vol. 5, no. 1, pp. 136-157, 1991.

[13] "8 Law Schools on Cutting Edge of Tech + Innovation," Innovative Law Student, 28-Apr-2016. [Online]. Available: https://www.innovativelawstudent.com/2016/04/7-lawschools-cutting-edge-tech-innovation/. [Accessed: 20-Jul2019].

[14] I. A. Rabb and S. Tai, "Digital Islamic Law: Purpose and Prospects," Int. J. Middle East Stud. Camb., vol. 50, no. 1, pp. 113-118, Feb. 2018.

[15] K. P. Lee, "The Citizen Lawyer in the Coming Era: Technology is Changing the Practice of Law, but Legal Education Must Remain Committed to Humanistic Learning," Ohio North. University Law Rev., vol. 40, no. 1, pp. 1-38, 2013. 